\title{
И.В. Чечик
}

Аннотация. Статья посвящена одной из актуальньх проблел совреленной лингводидактики - поиску путей оптилизации процесса обучения иностраннолу языку, в частности, руссколу языку как иностраннолу в ралках проббессионально-ориентированного подхода. Обосновывая актуальность использования аудиовизуальньх средств в процессе обучения иностранных студентов технических спеииальностей, автор анализирует методический потенциал аудиовизуальных материалов, а также приводит прилерь заданий и бборл работь на занятиях по обучению языку специальности на русскол языке студентов инженерно-технического профбиля. В этол же контексте расслатривается и понятие "аутентичность" как важная характеристика аудиовизуальных средств, используемиая при их отборе для обучения. На основании опьта преподавателейпрактиков в статье подчеркивается необходилость учета культуроведческой и страноведческой иенности учебных аудиовизуальных материалов для борлирования соииокультурной, лингвострановедческой и профбессионально-коллуникативной колпетентности иностранных студентов будущих специалистов инженерно-технического профбиля. Авторол приводятся также методические приель и способы снятия языковых трудностей при восприятии аутентичного аудио- и видеотекста. Кроле того, кратко описывается и обучение стратегиял эбббективного слушания (effective listening strategies), использование технологии textmapping. Резюмируя изложенное в статье, автор делает ряд выводов об актуальности и результативности использования на занятиях по РКИ со студенталииностранцали совреленных аутентичных и оригинальных аудиовизуальных материалов в качестве средств обучения. При этол подчеркивается, что данная разновидность средств обучения позволяет педагогу в ралках профбессиональной подготовки в неязыковол вузе реализовать приниипы и 
положения профбессионально-ориентированного подхода, среди которьх особое значение илеют приниипь колмуникативности, кодифбиированности, наглядности, положительного элоционального ббона обучения, взаимосвязанного обучения всел видал речевой деятельности, что способствуют фборлированию у будущих специалистов коллуникативно-профбессиональной колпетентности.

Ключевые слова: русский язык как иностранный (РКИ), язык специальности, колмуникативно-профессиональная колпетентность, социокультурная колпетентность, лингвострановедческая колпетентность, аудиовизуальные средства обучения, аудирование, речевая деятельность, колмуникативный подход к обучению языку, эбббективнье стратегии слушания.

\section{THE RELEVANCE OF USING AUDIOVISUAL TEACHING AIDS IN RUSSIAN LANGUAGE CLASSES FOR FOREIGN STUDENTS OF ENGINEERING AND TECHNICAL PROFILE}

\section{I.V. Chechik}

Abstract. The article is devoted to one of the most actual problem of modern linguodidactics namely finding ways to optimize the process of teaching Russian as a Foreign Language in the context of job-oriented training. In the order to justify the relevance of using audio-visual aids at the lessons of Russian as a Foreign Language for engineering and technical profile students the author analyzes the methodological potential of audio-visual aids and describes some teaching techniques to facilitate listening comprehension of authentic audio-visual texts, for example effective listening strategies and textmapping. The concept of authenticity of audio-visual aids as a very important criterion for educational purposes is substantiated in the article. Taking into account the modern teachers experience the author emphasizes the importance of the cross-cultural value of audio-visual training materials for building cross-cultural competence as one of the most important characteristic of successful engineers and technicians. The article concluded that using modern authentic and original audio-visual aids in the process of studying Russian as a foreign language based on the principle of clarity, the principle of interconnected learning to types of speech activity, the principle of authenticity, the principle of interactivity, communicative and professional competence, is an effective way to constitute communicative and professional competence of foreign engineering and technical profile students.

Keywords: Russian as a foreign language, Russian as a language for specific purposes, communicative and professional competence, social and cultural competence, linguistic and cultural competence, audiovisual educational aids, listening comprehension, speaking competence, communicative approach to language learning, effective strategies of listening. 
настоящее время глобальные процессы, происходящие в экономике и обществе, влияют не только на процессы модернизации образования [1], но и заставляют пересмотреть требования к выпускникам российских вузов [2]. Среди которых, в условиях действующего компетентностного подхода к профрессиональной подготовке [3; 4], одним из ключевых остается их конкурентноспособность, базирующаяся на умениях в области деловой коммуникации в профессиональном общении, в том числе, на иностранном языке в сфрере науки, техники, технологий и профессии. Возрастающая роль иностранного языка и русского как иностранного, в частности, в неязыковых вузах нашей страны нашла свое отражение в современном федеральном государственном образовательном стандарте высшего образования.

Так, будущий специалист - выпускник вуза, освоивший программу бакалавриата по направлению 07.03.01 «Архитектура» и 08.03.01 «Строительство», должен обладать: «способностью к коммуникации в устной и письменной формах на русском и иностранном языках для решения задач межличностного и межкультурного общения»; владеть «способностью к самоорганизации и саморазвитию»; оперировать "одним из иностранных языков на уровне профрессионального общения и письменного перевода». Выпускник должен обладать способностью «осуществлять деловую коммуникацию в устной и письменной формах на государственном языке Российской Федерации и иностранном(ых) языке(ах)». Таким образом, парадигма образования сегодня сместилась с усвоения знаний, умений и навыков, накопленных предыдущими поколениями, на обучение поиску и добыче новой информации, самообразованию, саморазвитию.

Многие исследователи (среди них И.Л. Бим, Н.Д. Гальскова, Р.П. Мильруд, А.А. Миролюбов, Е.И. Пассов, В.В. Сафонова, С.Г. Тер-Минасова и др.) видят целью изучения в неязыковом вузе иностранного языка и русского языка как иностранного, в частности, развитие способности и формирование готовности выпускника использовать иностранный язык в своей профессиональной деятельности в условиях нового поликультурного и полиязыкового пространства [4; 5]. Как отмечает И.А. Ткачева, «подготовка специалистов в неязыковых вузах <..> заключается в фрормировании коммуникативных умений, позволяющих осуществлять профрессиональные контакты на иностранном языке в различных сфрерах и ситуациях делового характера» [6, с. 33].

Общеизвестно, что использование аудиовизуальных материалов на занятиях по обучению русскому языку как иностранному дает возможность преподавателю презентовать учебный материал в наиболее доступной для восприятия и запоминания форме.

В современной лингводидактике под аудиовизуальными средствами обучения понимают технические средства обучения, включая не только учебное кино, но и аутентичные радио- и телепередачи, звукозапись, видеофильмы телекомпаний, видеоролики и репортажи, размещенные на различных интернет ресурсах [7].

Аудиовизуальные средства подразделяются на [8, с. 22]:

- учебные, специально предназначенные для занятий языком и со- 
держащие методически обработанный учебный материал (наглядные пособия);

- учебные, созданные для занятий по другим дисциплинам, но привлекаемыми в качестве учебных материалов по языку (средства наглядности);

- естественные, содержащиеся в средствах массовой коммуникации, включаемые в учебный процесс.

Использование аудиовизуальных средств на занятиях по обучению русскому языку как иностранному позволяет воспринимать обучающимися учебный материал в нагляднообразной форме, тем самым обеспечивать адекватное понимание и запоминание учебной информации современными студентами.

C позиции теории поколений (Ю.А. Левада, Н. Хоув, Т. Шанин, E.M. Шамис, У. Штраус и др.) это объясняется тем, что для поколений $Y$ и $Z$ характерно доминирование визуального канала получения информации. В связи с этим визуальная концептуализация является оптимальной стратегией использования учебных материалов [9]. Исследователи отмечают, что сильное педагогическое воздействие аудиовизуальных средств проявляется еще и в том, что фракты, события, явления излагаются с помощью художественных средств выражения (кино-, фротосъемка, живопись, музыка и др.), что обеспечивает принцип положительного эмоционального фона обучения [7].

Высокая информативная насыщенность аудиовизуального контента позволяет оптимизировать процесс обучения. Аудиовизуальные средства дают возможность обучаемым не только тренировать аудитивные навыки, но и увидеть изучаемые явления в реальном контексте, познакомиться с современными достижениями науки и техники, предметами и явлениями культуры страны изучаемого языка. Это существенно активизирует учебную мотивацию студентов.

В данном контексте важно подчеркнуть, что эфрдективные современные педагогические технологии в рамках профессионально-ориентированного подхода к обучению, например, иноязычному общению, придерживаются принципа культуроведческой и страноведческой ценности учебных материалов, тематически релевантных профрессиональным интересам будущих специалистов и способных служить результативной основой для формирования у них фроновых знаний и понятий [10-12].

Таким образом, применение аудиовизуальных средств в процессе обучения русскому языку как иностранному направлено, в том числе, и на формирование социокультурной и лингвострановедческой, социальнокоммуникативной и профессионально-коммуникативной компетентности будущих специалистов [13-17].

Работу со специальной литературой и иными материалами на языке оригинала на занятиях по изучению иностранных языков в рамках профессионально-ориентированного обучения можно считать традиционной. На современном этапе развития отечественная и зарубежная лингводидактика предлагает опираться на принцип аутентичности при отборе обучающего аудиовизуального материала и его контентном планировании. Многие методисты справедливо 
полагают, что именно аутентичные материалы, в отличие от специально подготовленных преподавателямирусистами, способствуют формированию корректных знаний будущих специалистов инженерно-технического профиля и препятствуют появлению когнитивного диссонанса [13].

Однако существует определенная неясность в разграничении понятий «аутентичный», «подлинный» и «оригинальный», что ведет к неточности в определении критериев «аутентичности» учебных материалов. Отечественные исследователи поразному трактуют понятие аутентичных учебных материалов. В переводе с греческого «аутентичный», «аутентический» (гр. authenticos) означает подлинный, исходящий из первоисточника. Э.Г. Азимов и А.Н. Щукин в своем словаре дают следующее определение аутентичным материалам: «Материалы для изучающих язык, которые используются в реальной жизни страны» [8, с. 25]. Следовательно, в современной лингводидактике под аутентичными понимают материалы, которые создавались носителями языка, но в дальнейшем без изменений нашли свое применения в учебном процессе, ориентированном на коммуникативный подход к обучению иностранному языку.

Г.Р. Чумарина, вслед за К.С. Кричевской [14], разделяет понятия аутентичные и учебно-аутентичные материалы. При этом к аутентичным автор относит материалы, взятые из оригинальных источников, которые характеризуются ситуативной адекватностью используемых языковых средств, естественностью лексикограмматического наполнения, иллюстрируют случаи аутентичного сло- воупотребления. Данные тексты не предназначены для учебных целей, но могут быть использованы при обучении иностранному языку.

К учебно-аутентичным материалам исследователь относит материалы, специально разработанные носителем языка с учетом всех параметров аутентичного процесса и критериев аутентичности и предназначены для решения конкретных учебных задач. К аутентичным видеоматериалам Н.Н. Сергеева и А.Е. Чикунова [18] относят видеозаписи, созданные носителями языка и предназначенные для носителей языка, которые содержат лингвистическую и экстралингвистическую информацию из различных сфер жизни общества, связанных с профессиональной деятельностью будущих специалистов и показывают функционирование языка как средства продессиональной коммуникации в естественном окружении. Однако опора только на такой критерий, как «носитель языка", по нашему мнению, оказывается недостаточной, когда речь идет об обучении языку специальности студентов инженерно-технического профиля.

В нашей работе мы придерживаемся критериев, разработанных коллективом авторов Станкиновской научно-методической школы И.Б. Авдеевой, Т.В. Васильевой, Г.М. Левиной и С.И. Досько [13]. По их мнению, основной набор так называемых аутентичных материалов при обучении иностранных студентов в технических вузах составляют учебники по инженерным дисциплинам, по своему жанру относящиеся к письменной разновидности научного стиля речи. $К$ устной разновидности 
научного стиля речи относятся диалоги и полилоги на темы специальности как между самими обучаемыми, так и между студентом и преподавателем (лекции, семинары, практические занятия). Также отмечается, что тексты учебников инженернотехнических дисциплин ориентированы на определенного адресата русскоязычного студента, который в рамках довузовской подготовки обладает определенными базовыми знаниями в области точных наук, владеет терминологическим аппаратом, умеет читать схемы, чертежи. Таким обра3ом, «в терминологии когнитивной науки адресант и адресат имеют общее знание (common knowledge)» то, что они в силу частичной общности образования знали еще до данного акта общения, в процессе которого будут вырабатывать совместное знание (shared knowledge). Именно общее знание авторы кладут в основу выделения понятия «аутентичный».

Согласно И.Б. Авдеевой, Т.В. Васильевой, Г.М. Левиной, С.И. Досько [13], под аутентичным инженерным текстом авторы подразумевают текст, принадлежащий учебно-научному и научно-техническому подстилям и написанный преподавателем-инженером для инженера (или будущего инженера), т.е. в рамках одной социальной группы, имеющей характерные языковые особенности. К устной разновидности аутентичного текста авторы относят диалоги и полилоги на профрессиональные темы между инженерами, а также магистрантами и аспирантами, которые являются уже дипломированными специалистами. Критерием аутентичности в обоих случаях является моносоциумная коммуникация, базирующая- ся на общих знаниях (common knowledge) и проявляющаяся в кодифицированности речи.

Таким образом, исследователи пришли к заключению, что научнопопулярные, научно-публицистические тексты, которые традиционно объединяются с учебно-научными и научными применительно к инженерно-техническим специальностям, не являются аутентичными, так как не отвечают условиям кодифищированности речи и моносоциумности коммуникантов. Такого рода тексты при условии их неадаптированности уместно называть оригинальными, а ситуации речевого общения, характерные для конкретной профрессиональной сореры, подлинными ситуациями. К ним относятся проведение эксперимента, лабораторной работы, научного диспута, а также беседа студентов с преподавателем, например, русского языка или профильных дисциплин.

На наш взгляд, к этому списку можно добавить интервью специалиста для специалистов или для будущих специалистов в данной области - студентов. Следовательно, использование на занятиях аудиовизуальных материалов из популярных источников, например, из цикла научно-популярных передач телеканала «Наука 2.0», относятся к оригинальным материалам, так как они подготовлены не инженерами, а журналистами для широкой аудитории. Аутентичными могут быть только интервью с техническими специалистами, а производственные ситуации или научные эксперименты, показанные в данных видеофильмax, можно считать подлинными.

В свете всего вышеизложенного можно сделать вывод, что в рамках 
подготовки к занятиям по языку специальности инженерно-технического профиля при отборе аудиовизуального материала из популярных источников необходимо ориентироваться на критерии кодифицированности речи и моносоциумности коммуникатнов. Однако, с другой стороны, визуальный контент, отражающий реальные производственные ситуации или научные эксперименты, может служить наглядной иллюстрацией к научному тексту.

Актуальность применения аудиовизуальных средств при обучении русскому языку как иностранному раскрывается также через принцип коммуникативной направленности процесса обучения. Опора на данный принцип, ориентированный на развитие коммуникативной компетенции, при обучении профессионально-ориентированному общению является общим трендом современной отечественной и зарубежной методики [8; 19-23].

По нашему мнению, традиционная для коммуникативной методики фороула «три П» (presentation practice - production / PРP), подробно описанная Д. Эвансом (Evans [22]) и активно используемая отечественными методистами при обучении русскому языку как иностранному, среди них [23, с. 54; 24], прекрасно работает при использовании аудиовизуального материала на занятиях по обучению русскому языку как иностранному. Например, некоторые занятия по русскому языку для студентов-иностранцев 1 курса архитектурного и строительного фракультетов СПбГАСУ проходят с использованием эпизодов из различных видеофильмов, посвященных уникальным зданиям и сооружениям России [25-27]. Фрагменты видеофильмов (2-2,5 мин.) содержат видеоряд и закадровое описание технических характеристик гидротехнических сооружений, высотного здания, скоростной шестиполосной автодороги, а также конструкций автомобильного тоннеля, большепролетного автомобильного и железнодорожного мостов, панорамные съемки на местности, интервью с техническими специалистами.

Практика показывает, что усвоение лексики по темам: «конструктивная схема здания», «автомобильный тоннель», «скоростная автодорога», «здания и сооружения» и «фундаменты», а также лексико-грамматических конструкций, характерных для научного стиля речи, происходит эффективнее, так как студентам предъявляются аудиовизуальные материалы, презентующие употребление изучаемых языковых единиц в реальных ситуациях словоупотребления. Так, на этапе презентации (presentation) материала используются упражнения на анализ и наблюдение тех или иных грамматических явлений в речи, например, «послотрите видеобраглент, слушайте и записывайте отглагольные существительные»; на развитие языковой догадки и антиципации, например, "послотрите интервью инженера. Попробуйте догадаться, о чел ми сегодня будел говорить». На этапе практики (practice) снятие фронетических, лексических и грамматических трудностей (чтение лексико-грамматического комментария, выполнение письменных грамматических упражнений) подкрепляется различными заданиями на аудирование, с элементами конспектирова- 
ния, повторение за спикером. На этапе продукции (production) предлагаются проверочные условно-коммуникативные и коммуникативные упражнения на тренировку различных видов говорения по «разворачиванию» созданных в результате просмотра опорных конспектов в высказывания. Интересно отметить, что насыщенный видеоряд и впечатляющие масштабы технических объектов вызывают у обучаемых живой интерес и стимулируют их к дискуссии и обмену мнениями.

Несмотря на то, что использование аутентичных и оригинальных аудио и видеотекстов на занятиях по изучению русского языка как иностранного позволяет развивать навыки аудирования в реальных ситуациях общения, многие преподавателипрактики намеренно не используют данные материалы в своей работе изза их объективной сложности для иностранных обучающихся [28]. Восприятие иностранными студентами звучащей речи сильно осложняют фонетические особенности и быстрый темп речи спикеров, разнообразные шумы, вызванные звуками окружающей среды. В этой связи интересны идеи зарубежных методистов, которые полагают, что акцент в обучении необходимо делать не на сложности предлагаемого учебного материала, а на том задании, которое необходимо выполнить с данным текстом. В связи с этим, большое внимание исследователи уделяют анализу стратегий әффективного слушания (strategies for effective listening) и учебных заданий, ориентированных на развитие данных стратегий [19-21].

Проанализировав данные источники, автор разделяет все стратегии на шесть групп [20], которые условно можно перевести, как:

- слушание в целях формулирования общего смысла;

- слушание в целях получения конкретной информации;

- слушание в целях предположения конкретной информации;

- слушание в целях сравнения новой информации с имеющейся;

- слушание в целях выявления ключевых понятий/слов/главной идеи

- слушание в целях составления заключения,

- слушание в целях понимания намерений спикера по невербальным знакам.

Таким образом, как иностранные методисты Х. Браун (Brown [19]), Дж. Вилсон (Wilson [20]), Д. Нуннан (Nunnan [21]), так и отечественные [23-24] рекомендуют в целях развития аудитивных навыков у студентов формулировать задания, ориентируясь на данные типы стратегий. В нашем случае задания, ориентированные на понимание общего смысла и развитие языковой догадки, предваряют основную работу с аудиовизуальным материалом. Например, «послушайте аудиотекст, о чел в обиел говорит инженер?»; "послотрите первые кадры фбильла, как вь думаете, о чем сегодня пойдет речь?" Поиск/запоминание/повтор конкретной информации в аудиотексте / видеофрагменте целесообразно задавать после отработки нового лексико-грамматического материала. Например, «прослушайте аудиотекст, запишите все отглагольные существительные с суббббиксол -ени, -ани». Также нами предлагаются следующие задания на тренировку слухопроизносительного навыка и снятия 
лексических трудностей: "слушайте u повторяйте за спикером слова и словосочетания"; "прослушайте $u$ запишите слова и словосочетания. Полните о процессах редукиии и ассилиляиии в русских словах, а также на стыке слов». Традиционно на данном этапе используются задания на заполнение пропусков слов в скрипте аудиотекста.

Интересными представляются разработки зарубежных и отечественных методистов, направленные на оптимизацию процесса восприятия и запоминания информации. В частности, технологии «textmapping» (технология свитка). Автор данного методического приема Дейв Миддлбрук [29] использует его для работы с письменными текстами нехудожественных произведений в разнообразных аудиториях: школьники, студенты, пенсионеры, - и убедительно доказывает высокую эфрективность такой работы по сравнению с традиционным способом анализа письменного текста. В нашем случае работа ведется на индивидуальном раздаточном материале - стопкадрах. Учащимся дается задание на распределение стоп-кадров в нужной последовательности для записи на них необходимой конкретной информации. Например, «прослушайте описание технических характеристик конструкиий моста. Заббиксируйте их характеристики на cmon-кадрах». Далее возможно организовать работу в паpax/ малых группах для проверки знаний и тренировки навыков диалогического и монологического говорения. Важно отметить, что такого рода наглядный опорный конспект легче трансформируется в полноцен- ное высказывание, а использование интерактивных методик в сочетании с принципом наглядности во много раз повышает качество работы с аудиовизуальным материалом.

В качестве домашнего задания предлагается самостоятельно подготовить презентацию/доклад на темы: «Уникальные здания и сооружения в моей стране / в мире», «Проблемы высотного строительства в моей стране» и т.д. Применение данного типа заданий в аспекте межкультурной коммуникации является непременным условием налаживания диалога культур и гармонизации межэтнических отношений в учебной группе. Учет культуры, традиций, обсуждение достижений науки и техники родной страны студентов в процессе изучения русского языка, несомненно, стимулирует учебно-познавательную их мотивацию.

В качестве отработки стратегии определения новой / старой (уже известной) информации целесообразно использовать задания-таблицы с заголовками «правда / неправда / не было информации в тексте» или «знал (-а) / узнал (-а)». Развитию стратегии формирования аналитического восприятия учебной информации способствуют такие методические приемы, как: составление денотатного графра, составление диаграммы Исикавы, больше известной, как «fishbone» [30].

Многие преподаватели-практики сходятся во мнении, что данные приемы структурного анализа причинно-следственных связей позволяют развивать критическое мышление, ранжировать фракты по степени их актуальности / значимости, в наглядно-содержательной форме актуализировать взаимосвязи между 
причиной и следствием, а также дают возможность организовать работу участников в парах и группах. Также необходимо отметить, что использование на занятии обучающих материалов из нескольких источников воспринимается студентами положительно, способствует развитию их критического мышления, а также поддерживает учебную мотивацию. Например, «послотрите фбраглент видеоббильла о Крылискол мосте, дополните инборлацию даннылми из текста».

Таким образом, в нашей разработке, студенты-иностранцы не только осваивают лексику по языку специальности, но и наглядно знакомятся с такими грандиозными и уникальными современными техническими объектами России, как комплекс защитных сооружений СанктПетербурга от наводнений [25], Лахта Центр в Санкт-Петербурге [26], Крымский мост [27] и др.

Подводя итог, мы приходим к следующему выводу: использование на занятиях наряду с письменными текстами аудиовизуального материала позволяет комплексно подходить к решению проблемы обучения русскому языку как иностранному студентов инженерно-технических специальностей, поскольку:

- введение и закрепление новой лексико-грамматической информации происходит эффрективнее, поскольку опирается на зрительно-слуховые образы;
- в процессе прослушивания аудио и видеозаписей происходит интенсивная тренировка навыков аудирования и конспектирования.

- учет принципов профессионально-ориентированного обучения при отборе и контентном планировании использования аудиовизуальных материалов, дает возможность поддерживать мотивацию студентов, а также стимулирует их речемыслительную и учебно-познавательную активность;

- использование методических приемов и способов, ориентированных на принципы коммуникативности, интерактивности, аутентичности, взаимосвязанного обучения всем видам речевой деятельности, в работе с аудиовизуальным контентом способствует формированию коммуникативно-профессиональной компетентности будущих специалистов;

- яркие зрительные образы, созданные с помощью разнообразных художественных средств выражения, содержащие информацию о культуре, истории и достижениях науки и техники, способствуют формированию социокультурной и лингвострановедческой компетенции иностранных студентов - будущих специалистов.

- работа с аутентичными и оригинальными аудиовизуальными материалами, построенная на принщипах межкультурной коммуникации, положительно влияет на гармонизацию отношений в учебной группе и способствует налаживанию диалога культур.

\section{СПИСОК ИСТОЧНИКОВ И ЛИТЕРАТУРЫ}

1. Лубков А.В., Каракозов С.Д., Рыэжова Н.И. Тенденции развития современного образования в условиях становления цифровой экономики // Информатизация образования: теория и практика: сборник матер. Межд. науч.-практ. конф. 18-19.11.2017 г. Омск: Изд-во ОмГПУ, 2017. С. 41-47. 
2. Маршалова Е.С., Рыжова Н.И. Тенденции профессиональной подготовки специалиста в области корпоративных маркетинговых коммуникаций с учетом конъюнктуры рынка труда и взаимодействия с работодателями // Преподаватель XXI век. 2019. № 2-1. С. 4-46.

3. Литвиненко М.В., Рыжова Н.И. Профессиональная подготовка специалистов топографогеодезического профиля в логике компетентностного подхода // Известия высших учебных заведений. Геодезия и аэрофотосъемка. 2007. № 1. С. 170-176.

4. Анисина Ю.В. Становление и развитие профессионально ориентированного обучения русскому языку как иностранному на неязыковых факультетах вузов России // Научный диалог: Психология. Педагогика. 2013. № 9 (21). С. 83-91.

5. Вовси-Тиллье Л.А. Современные цели обучения иностранным языкам в неязыковом вузе // Педагогический журнал. 2018. Т. 8. № 3А. С. 132-137.

6. Ткачева И.А. Профессионально ориентированное обучение иноязычной речи студентов вузов // Теория и практика сервиса: экономика, социальная сфера, технологии. 2013. № 1 (15). С. 31-38.

7. Кочергина В.И. Аудиовизуальные средства обучения в образовательном процессе // Социльная сеть работников образования nsportal.ru. URL: https://nsportal.ru/shkola/ obshchepedagogicheskie-tekhnologii/library/2018/03/05/audiovizualnye-sredstva-obucheniya-v (дата обращения: 15.10.2019).

8. Азимов Э.Г., Щукин А.Н. Новый словарь методических терминов и понятий (теория и практика обучения языкам). М.: Издательство ИКАР, 2009. 448 с.

9. Тенхунен П.Ю., Елисеева Ю.А. Особенности восприятия учебной информации современными студентами: потенциал визуальной концептуализации // Интеграция образования. 2015. Т. 19. № 4. C. 28-34.

10. Массалова А.Э. Особенности развития учебной мотивации на уроках русского языка как иностранного для военнослужащих инженерных специальностей // Педагогическое образование в России. Русский язык. 2016. № 16. С. 110-113.

11. Гадоев К.X. Использование лингвострановедческих материалов при интегрированном обучении иностранному языку в неязыковых вузах / Образование: прошлое, настоящее и будущее: материалы IV Междунар. науч. конф. (г. Краснодар, февраль 2018 г.). Краснодар: Новация, 2018. С. 111-114.

12. Литвиненко Ю.Ю. Методический потенциал аудиовизуальных средств на занятиях по русскому языку как иностранному (из опыта работы) // Гуманитарные исследования. 2016. № 4 (13). С. 81-82.

13. Авдеева И.Б., Васильева Т.В., Левина Г.М., Досько С.И. Теория обучения русскому языку учащихся инженерного профиля // Научный вестник МГТУ ГА. Серия Международная деятельность вузов. 2008. № 128. С. 77-81.

14. Чумарина Г.Р. Использование аутентичных материалов в процессе обучения иностранному языку // Образовательный портал России Инфоурок. URL: https://infourok.ru/statyaispolzovaniya-autentichnih-materialov-v-processe-obucheniya-inostrannomu-yaziku-2544756. $\mathrm{html} /$ (дата обращения: 16.10.2019).

15. Дудина Г.О., Чечик И.В. Ресурсы масс-медиа как средство формирования профессионально-коммуникативной компетентности иностранных студентов на занятиях по РКИ // Мир науки, культуры, образования. 2019. № 5(78). С. 262-264.

16. Медянова П.В., Рыжова Н.И. Структура и компоненты языковой составляющей социальнокоммуникативной компетентности специалиста туристской индустрии // Мир науки, культуры, образования. 2012. № 3(34). С. 8-12. 
17. Чечик, И.В. Работа с рекламным текстом на уроках по русскому языку и культуре речи для студентов менеджеров // Материалы 72-ой науч. конф. «Архитектура-Строительство-Транспорт». СПб, 2016. С. 43-45.

18. Сергеева Н.Н., Чикунова, А.Е. Аутентичные видеоматериалы как средство развития социокультурной компетенции студентов экономических специальностей // Педагогическое образование в России. 2011. № 1. С. 147-157.

19. Brown H.D. Teaching by principles: an interactive approach to language pedagogy (2nd ed.), While Plains, NY: Pearson Education, 2001, 259 p.

20. Wilson J.J. How to teach Listening. Pearson Education (Longman), 2015, $192 \mathrm{p}$.

21. Nunnan D. Second language teaching and learning, Boston. Heile \& Heile, Publishers, 2001, 219 p.

22. Evans D. A Review of PPP, University of Birmingham. 1999, $11 \mathrm{p}$.

23. Балыхина T.M. Методика преподавания русского языка как неродного (нового): учебное пособие для преподавателей и студентов. М.: Изд-во Российского университета дружбы народов, 2007. $185 \mathrm{c}$.

24. Занкова А.А. К практике использования коммуникативного подхода в преподавании русского языка как иностранного // Международный информационно-аналитический журнал «Crede Experto: транспорт, общество, образование, язык». № 4 (11). Декабрь 2016. URL: http:/ce.if-mstuca.ru/wp-content/uploads/2016/04/zankova.pdf (дата обращения 18.10.2019).

25. Дамба Санкт-Петербурга. Уникальный щит [Видеофильм] // Телекомпания RTG TV. 2015. URL: https://ok.ru/video/664249043492/ (дата обращения: 19.10.2019).

26. Лахта Центр. Город технологий [Видеоресурсы]. URL: https://yandex.ru/search/?text=\%D0\%B 2\%D0\%B8\%D0\%B4\%D0\%B5\%D0\%BE\%D1\%84\%D0\%B8\%D0\%BB\%D1\%8C\%D0\%BC\%20 \%D0\%BE\%20\%D0\%9B\%D0\%B0\%D1\%85\%D1\%82\%D0\%B0-\%D1\%86\%D0\%B5\%D0\%BD\% D1\%82\%D1\%80\%D0\%B5\&lr=2\&clid=1955454\&win=105\#/videowiz?filmId=62326331779788 34073/ (дата обращения: 19.10.2019).

27. Крымский мост [Видеофильм] // Телекомпания RTД. 2018. URL: https://www.youtube.com/ watch?v=0otwInqG7B4\#action=share/ (дата обращения: 19.10.2019).

28. Батраева О.В. Использование видеоматериалов на занятиях по языку специальности иностранных учащихся, изучающих русский язык в техническом вузе // Электронный научный журнал «Apriori. Серия: гуманитарные науки». 2015. № 3. URL: https://www.apriori-journal. ru/seria1/3-2015/Batraeva.pdf (дата обращения:18.10.2019).

29. Проект Textmapping // URL: http://www.textmapping.org/ (дата обращения: 19.10.2019).

30. Мухортова Н.В. Метод «фишбоун» как один из способов развития критического мышления // Электронный журнал Экстернат РФ, социальная сеть для учителей. URL: http://ext.spb. ru/2011-03-29-09-03-14/110-foreignlang/11361-Metod_\%C2\%ABFishboun\%C2\%BB_kak_odin_ iz_sposobov_razvitiya_kriticheskogo_myshleniya.html/ (дата обращения: 18.10.2019).

\section{REFERENCES}

1. Anisina Yu.V. Stanovlenie i razvitie professionalno orientirovannogo obucheniya russkomu yazyku kak inostrannomu na neyazykovyh fakultetah vuzov Rossii, Nauchnyi dialog: Psihologiya. Pedagogika, 2013, No. 9 (21), pp. 83-91. (in Russian)

2. Avdeeva I.B., Vasileva T.V., Levina G.M., Dosko S.I. Teoriya obucheniya russkomu yazyku uchashihsya inzhenernogo profilya, Nauchnyi vestnik MGTU GA. Seriya Mezhdunarodnaya deyatelnost vuzov, 2008, No. 128, pp. 77-81. (in Russian) 
3. Azimov E.G., Shukin A.N. Novyi slovar metodicheskih terminov i ponyatii (teoriya i praktika obucheniya yazykam). Moscow, Izdatelstvo IKAR, 2009, 448 p. (in Russian)

4. Balyhina T.M. Metodika prepodavaniya russkogo yazyka kak nerodnogo (novogo): uchebnoe posobie dlya prepodavatelei i studentov, Moscow, Izd-vo Rossiiskogo universiteta druzhby narodov, 2007, 185 p. (in Russian)

5. Batraeva O.V. Ispolzovanie videomaterialov na zanyatiyah po yazyku specialnosti inostrannyh uchashihsya, izuchayushih russkii yazyk v tehnicheskom vuze, Elektronnyi nauchnyi zhurnal «Apriori. Seriya: gumanitarnye nauki», 2015, No. 3, available at: https://www.apriori-journal.ru/ seria1/3-2015/Batraeva.pdf (accessed: 18.10.2019). (in Russian)

6. Brown H.D. Teaching by principles: an interactive approach to language pedagogy (2nd ed.), While Plains, NY, Pearson Education, 2001, 259 p.

7. Chechik I.V. "Rabota s reklamnym tekstom na urokah po russkomu yazyku i kulture rechi dlya studentov menedzherov“, in: Materialy 72-oi nauchnoy konferentsii «Arhitektura-Stroitelstvo Transport», Sankt-Petersburg, 2016, pp. 43-45. (in Russian)

8. Chumarina G.R. Ispolzovanie autentichnyh materialov v processe obucheniya inostrannomu yazyku, in: Obrazovatelnyi portal Rossii Infourok, available at: https://infourok.ru/statya-ispolzovaniyaautentichnih-materialov-v-processe-obucheniya-inostrannomu-yaziku-2544756.html/ (accessed: 16.10.2019). (in Russian)

9. Damba Sankt-Peterburga. Unikalnyi shit [Videofilm], Telekompaniya RTGTV, 2015, available at: https://ok.ru/video/664249043492/ (accessed: 19.10.2019). (in Russian)

10. Dudina G.O., Chechik I.V. Resursy mass-media kak sredstvo formirovaniya professionalno-kommunikativnoi kompetentnosti inostrannyh studentov na zanyatiyah po RKI, Mir nauki, kultury, obrazovaniya, 2019, No. 5(78), pp. 262-264. (in Russian)

11. Evans D. A Review of PPP. University of Birmingham, 1999, 11p.

12. Gadoev K.H. "Ispolzovanie lingvostranovedcheskih materialov pri integrirovannom obuchenii inostrannomu yazyku v neyazykovyh vuzah“, in: Obrazovanie: proshloe, nastoyashee i budushee: materialy IV Mezhdunar. nauch. konf. (g. Krasnodar, fevral 2018 g.), Krasnodar, Novaciya, 2018, pp. 111-114. (in Russian)

13. Kochergina V.I. Audiovizualnye sredstva obucheniya v obrazovatelnom processe, Socilnaya set rabotnikov obrazovaniya nsportal.ru, available at: https://nsportal.ru/shkola/obshchepedagogicheskie-tekhnologii/library/2018/03/05/audiovizualnye-sredstva-obucheniya-v (accessed: 15.10.2019). (in Russian)

14. Krymskii most [Videofilm], Telekompaniya RTD, 2018, available at: https://www.youtube.com/wa tch? $\mathrm{v}=0$ otwInqG7B4\#action=share/ (accessed: 19.10.2019). (in Russian)

15. Lahta Centr. Gorod tehnologii [Videoresursy], available at: https://yandex.ru/search/?text=\%D0\% B2\%D0\%B8\%D0\%B4\%D0\%B5\%D0\%BE\%D1\%84\%D0\%B8\%D0\%BB\%D1\%8C\%D0\% B C \% $20 \%$ D $0 \%$ B E \% $20 \%$ D $0 \% 9$ B \% D $0 \%$ B $0 \%$ D $1 \% 85 \%$ D $1 \% 82 \%$ D $0 \%$ B 0 $\% \mathrm{D} 1 \% 86 \% \mathrm{D} 0 \% \mathrm{~B} 5 \% \mathrm{D} 0 \% \mathrm{BD} \% \mathrm{D} 1 \% 82 \% \mathrm{D} 1 \% 80 \% \mathrm{D} 0 \% \mathrm{~B} 5 \& 1 \mathrm{r}=2 \& \mathrm{clid}=1955454 \&$ win=105\#/vid eowiz?filmId=6232633177978834073/ (accessed: 19.10.2019). (in Russian)

16. Litvinenko M.V., Ryzhova N.I. Professionalnaya podgotovka specialistov topografo-geodezicheskogo profilya v logike kompetentnostnogo podhoda, Izvestiya vysshih uchebnyh zavedenii. Geodeziya i aerofotosemka. 2007, No. 1, pp. 170-176. (in Russian)

17. Litvinenko Yu.Yu. Metodicheskii potencial audiovizualnyh sredstv na zanyatiyah po russkomu yazyku kak inostrannomu (iz opyta raboty), Gumanitarnye issledovaniya, 2016, No. 4 (13), pp. 81-82. (in Russian) 
18. Lubkov A.V., Karakozov S.D., Ryzhova N.I. "Tendencii razvitiya sovremennogo obrazovaniya v usloviyah stanovleniya cifrovoi ekonomiki”, in: Informatizaciya obrazovaniya: teoriya i praktika: sbornik mater. Mezhd. nauch.-prakt. konf. 18-19.11.2017 g. Omsk, Izd-vo OmGPU, 2017, pp. 4147. (in Russian)

19. Marshalova E.S., Ryzhova N.I. Tendencii professionalnoi podgotovki specialista v oblasti korporativnyh marketingovyh kommunikacii s uchetom konyunktury rynka truda i vzaimodeistviya $\mathrm{s}$ rabotodatelyami, Prepodavatel XXI vek, 2019, No. 2-1, pp. 34-46. (in Russian)

20. Massalova A.E. Osobennosti razvitiya uchebnoi motivacii na urokah russkogo yazyka kak inostrannogo dlya voennosluzhashih inzhenernyh specialnostei, Pedagogicheskoe obrazovanie v Rossii. Russkii yazyk, 2016, No. 1, pp. 110-113. (in Russian)

21. Medyanova P.V., Ryzhova N.I. Struktura i komponenty yazykovoi sostavlyayushei socialno-kommunikativnoi kompetentnosti specialista turistskoi industrii, Mir nauki, kultury, obrazovaniya, 2012, No. 3(34), pp. 8-12. (in Russian)

22. Muhortova N.V. Metod «fishboun» kak odin iz sposobov razvitiya kriticheskogo myshleniya, Elektronnyi zhurnal "Eksternat $R F$ ", socialnaya set dlya uchitelei, available at: http://ext.spb.ru/2011-0329-09-03-14/110-foreignlang/11361-Metod_\%C2\%ABFishboun\%C2\%BB_kak_odin_iz_sposobov_razvitiya_kriticheskogo_myshleniya.html/ (accessed: 18.10.2019). (in Russian)

23. Nunnan D. Second language teaching and learning. Boston, Heile \& Heile, Publishers, 2001, $219 \mathrm{p}$.

24. Proekt Textmapping, available at: http://www.textmapping.org/ (accessed: 19.10.2019). (in Russian)

25. Sergeeva N.N., Chikunova, A.E. Autentichnye videomaterialy kak sredstvo razvitiya sociokulturnoi kompetencii studentov ekonomicheskih specialnostei, Pedagogicheskoe obrazovanie v Rossii, 2011, No. 1, pp. 147-157. (in Russian)

26. Tenhunen P.Yu., Eliseeva Yu.A. Osobennosti vospriyatiya uchebnoi informacii sovremennymi studentami: potencial vizualnoi konceptualizacii, Integratsiya obrazovaniya, 2015, T. 19, No. 4, pp. 28-34. (in Russian)

27. Tkacheva I.A. Professionalno orientirovannoe obuchenie inoyazychnoi rechi studentov vuzov, Teoriya i praktika servisa: ekonomika, socialnaya sfera, tehnologii, 2013, No. 1 (15), pp. 31-38. (in Russian)

28. Vovsi-Tille L.A. Sovremennye celi obucheniya inostrannym yazykam v neyazykovom vuze, Pedagogicheskii zhurnal, 2018, T. 8, No. 3A, pp. 132-137. (in Russian)

29. Wilson J.J. How to teach Listening. Pearson Education (Longman), 2015, 192 p.

30. Zankova A.A. "K praktike ispolzovaniya kommunikativnogo podhoda $\mathrm{v}$ prepodavanii russkogo yazyka kak inostrannogo", in: Mezhdunarodnyi informacionno-analiticheskii zhurnal "CredeExperto: transport, obshestvo, obrazovanie, yazyk». No. 4 (11), December, 2016, available at: http:// ce.if-mstuca.ru/wp-content/uploads/2016/04/zankova.pdf (accessed: 18.10.2019). (in Russian)

Чечик Ирина Владимировна, кандидат педагогических наук, доцент, кафедра русского языка, Санкт-Петербургский государственный архитектурно-строительный университет, ira_evl@mail.ru

Chechik I.V., PhD (Pedagogy), Associate Professor, Russian Language Department, Saint Petersburg State University of Architecture and Civil Engineering, ira_evl@mail.ru 